Nonohydr oxyl at ed pol ycycl i c ar omat i c hydrocar bons i nhi bit both osteocl ast i $c$ and ost eobl astic activities in tel eost scal es

\begin{tabular}{|c|c|}
\hline 著者 & $\begin{array}{l}\text { Suzuki Nobuo, Hayakawa Kazui chi, Kaneda } \\
\text { Takayuki, Tor i ba Aki ra, Tang N ng, Tabat a } \\
\text { Makot o J., Takada Koj i, Wada Shi gehi to, Onor i } \\
\text { Kat sunor i, Sri vast av Aj ai K, M shi ma } \\
\text { H r oyuki, Hat tor i At suhi ko }\end{array}$ \\
\hline $\begin{array}{l}\text { jour nal or } \\
\text { publ i cat } i \text { on } \mathrm{title}\end{array}$ & Li fe Sci ences \\
\hline vol une & 84 \\
\hline page $r$ ange & $13-14$ \\
\hline year & $2009-0327$ \\
\hline URL & ht t p: //hdl . handl e. net /2297/17058 \\
\hline
\end{tabular}




\title{
Monohydroxylated polycyclic aromatic hydrocarbons inhibit both osteoclastic and osteoblastic activities in teleost scales
}

\author{
Nobuo Suzuki ${ }^{1}$, Kazuichi Hayakawa ${ }^{2}$, Takayuki Kameda ${ }^{2}$, Akira Toriba $^{2}$, Ning Tang ${ }^{2}$, \\ Makoto J. Tabata ${ }^{3}$, Koji Takada ${ }^{4}$, Shigehito $\mathrm{Wada}^{5}$, Katsunori Omori ${ }^{6}$, Ajai K. Srivastav ${ }^{7}$, \\ Hiroyuki Mishima $^{8}$, and Atsuhiko Hattori ${ }^{9}$
}

${ }^{1}$ Noto Marine Laboratory, Institute of Nature and Environmental Technology, Kanazawa University, Noto-cho, Ishikawa 927-0553, Japan; ${ }^{2}$ Institute of Medical, Pharmaceutical and Health Sciences, Kanazawa University, Kakuma, Ishikawa 920-1192, Japan; ${ }^{3}$ Section of Biostructural Science, Graduate School of Tokyo Medical and Dental University, Bunkyo-ku, Tokyo 113-8549, Japan; ${ }^{4}$ Department of Biochemistry, Jikei University School of Medicine, Minato-ku, Tokyo 105-8461, Japan; ${ }^{5}$ Department of Oral and Maxillofacial Surgery, Faculty of Medicine, University of Toyama, Sugitani, Toyama 930-0194, Japan; ${ }^{6}$ Japan Aerospace Exploration Agency, Tsukuba, Ibaraki 305-8505, Japan; ${ }^{7}$ Department of Zoology, University of Gorakhpur, Gorakhpur 273009, India; ${ }^{8}$ Kochi Gakuen College, Kochi 780-0955, Japan; ${ }^{9}$ Department of Biology, College of Liberal Arts and Sciences, Tokyo Medical and Dental University, Ichikawa, Chiba 272-0827, Japan

Correspondence: Nobuo Suzuki

Noto Marine Laboratory, Institute of Nature and Environmental Technology, Kanazawa University, Noto-cho, Ishikawa 927-0553, Japan

Tel: +81-768-74-1151; Fax: +81-768-74-1644;

E-mail: nobuo@kenroku.kanazawa-u.ac.jp 


\begin{abstract}
Aims: We previously demonstrated that monohydroxylated polycyclic aromatic hydrocarbons (OHPAHs) bound to a human estrogen receptor (ER) by a yeast two-hybrid assay but polycyclic aromatic hydrocarbons did not have a binding activity. Therefore, the direct effect of 3-hydroxybenz $[a]$ anthracene (3-OHBaA) and 4-hydroxybenz $[a]$ anthracene (4-OHBaA) on osteoclasts and osteoblasts in teleosts was examined. As a negative control, 1-hydroxypyrene (1-OHPy), which has no binding activity to human ER, was used.

Main methods: The effect of OHPAHs on osteoclasts and osteoblasts was examined by an assay system using teleost scale as each marker: tartrate-resistant acid phosphatase for osteoclasts and alkaline phosphatase for osteoblasts. Changes in cathepsin K (an osteoclastic marker) and IGF-I (an osteoblastic marker) mRNA expressions in 4-OHBaA-treated goldfish scales were examined by using a reverse transcription-polymerase chain reaction.

Key findings: In both goldfish (a freshwater teleost) and wrasse (a marine teleost), the osteoclastic activity in the scales was significantly suppressed by 3-OHBaA and 4-OHBaA, although 1-OHPy did not affect the osteoclastic activity. In reference to osteoblasts, the osteoblastic activity decreased with both 3-OHBaA and 4-OHBaA and did not change with the 1-OHPy treatment. However, $17 \beta$-estradiol $\left(\mathrm{E}_{2}\right)$ significantly increased both the osteoclastic and osteoblastic activities in the scales of both goldfish and wrasse. The mRNA expressions of both cathepsin $\mathrm{K}$ and insulin-like growth factor-I decreased in the 4-OHBaA-treated scales but increased in the $\mathrm{E}_{2}$-treated scales, as did marker enzymes.
\end{abstract}

Significance: The current data are the first to demonstrate that 3-OHBaA and 4-OHBaA inhibited both osteoclasts and osteoblasts and disrupted the bone metabolism in teleosts.

Key words: monohydroxylated polycyclic aromatic hydrocarbons; teleost scale; osteoclasts; osteoblasts; bone metabolism; cathepsin K; insulin-like growth factor-I 


\section{Introduction}

Polycyclic aromatic hydrocarbons (PAHs) are ubiquitous environmental pollutants present in combustion products of fossil fuels, wood, and other organic materials (Lima et al. 2003) as well as in cigarette smoke (Lee et al. 2002).

In a previous study, using a yeast two-hybrid assay, we demonstrated that monohydroxylated polycyclic aromatic hydrocarbons (OHPAHs) bound to a human estrogen receptor (ER) but PAHs did not have a binding activity (Hayakawa et al. 2007). OHPAHs having four aromatic rings, such as 3-hydroxybenz $[a]$ anthracene (3-OHBaA) and 4-hydroxybenz $[a]$ anthracene (4-OHBaA), showed strong binding activity for human ER (Hayakawa et al. 2007). In rat cytosol as well, 2-hydroxybenz $[a]$ anthracene bound strongly to ER (Ebright et al. 1986). In the ER $\alpha$ reporter assay using a human breast cancer cell line (MCF-7), 3-OHBaA and 9-hydroxybenz[a]anthracene had binding activity to ER (Charles et al. 2000). In mammals, it is known that PAHs are converted into OHPAHs by an enzyme: cytochrome P4501A1 (Charles et al. 2000; Jaruchotikamol et al. 2007). In vivo, the endocrine disruptive action may be caused by OHPAHs but not by PAHs. Therefore, we believe that OHPAHs affect skeletal growth and development in mammals because estrogen acts on bone tissues (Chen et al. 2002; Liu et al. 2002). However, no report has been published regarding the direct effect of OHPAHs on bone tissues.

It is known that the scale tissue contains osteoclasts, osteoblasts, and bone matrix (Yamada 1961, 1971; Bereiter-Hahn and Zylberberg 1993; Suzuki et al. 2008). Recently, we detected both cathepsin $\mathrm{K}$ and tartrate-resistant acid phosphatase (TRAP) mRNA expression (Azuma et al. 2007) and TRAP enzyme activity (Persson et al. 1995, 1999) in the scale osteoclasts. In osteoblasts as well, type I collagen (Zylberberg et al. 1992), osteocalcin (Nishimoto et al. 1992), and osteonectin (Lehane et al. 1999), is present in the scales. In addition, we detected osteoblast-specific markers, such as alkaline phosphatase (ALP), runt-related transcription factor 2 (Runx 2), osterix, osteocalcin and the receptor activator of the NF- $\mathrm{B}$ ligand (RANKL)(unpublished data). In the fish 
skeletal tissue, the osteoblastic markers were detected (ALP: Witten 1997; Runx 2: Flores et al. 2004; RANKL: Glenney and Wiens 2004). Therefore, the features of osteoclasts and osteoblasts in scales are similar to those in mammals. Furthermore, the scales are a better potential internal calcium reservoir than the endoskeleton during periods of increased calcium demand, such as sexual maturation and starvation (Yamada 1961; Berg 1968; Mugiya and Watabe 1977; Bereiter-Hahn and Zylberberg 1993). In the case of mercury, a high correlation between the mercury level in the scales and that in the muscles has been reported in largemouth bass (Lake et al. 2006), although mercury did not accumulate in the vertebral bone of fish (Camusso et al. 1995). In teleosts, this indicates that the scale is a more active organ in the bone metabolism than in the endoskeleton. To analyze the bone metabolism, thus, we developed an in vitro assay system using teleost scales (Suzuki et al. 2000; Suzuki and Hattori 2002; Suzuki et al. 2007).

In the present study, we examined the direct effect of OHPAHs (3-OHBaA and 4-OHBaA) on scale osteoclasts and osteoblasts in both goldfish (a freshwater teleost) and wrasse (a marine teleost) and compared the results with those of 1-hydroxypyrene (1-OHPy), which had no binding activity to ER (Hayakawa et al. 2007) as a negative control. To confirm the obtained results, the mRNA expressions of cathepsin K (an osteoclastic marker) and insulin-like growth factor-I (IGF-I) (an osteoblastic marker) were examined in OHPAH-treated scales using a reverse transcription-polymerase chain reaction (RT-PCR). In addition, these results of OHPAHs were compared with those of $17 \beta$-estradiol $\left(\mathrm{E}_{2}\right)$.

The present study is the first to demonstrate that several OHPAHs affected the osteoclasts and osteoblasts of teleost scales and disrupted the bone metabolism in the scales.

\section{Materials and Methods}

\section{Animals}

A previous study (Suzuki et al. 2000) indicated that sensitivity to calcemic hormones was higher in 
mature female than in mature male teleosts. Therefore, female goldfish (Carassius auratus) were purchased from a commercial source (Higashikawa Fish Farm, Yamato-koriyama, Japan), and their scales were used in an in vitro assay. As a marine teleost, female wrasse (Pseudolabrus sieboldi) caught in Tsukumo Bay of Noto Peninsula were used. These fish were kept under normal conditions until the start of experiments.

All experimental procedures were conducted in accordance with the Guide for the Care and Use of Laboratory Animals of Kanazawa University.

\section{Effects of OHPAHs and $E_{2}$ on osteoclastic activity in cultured scales of goldfish and wrasse}

3-OHBaA, 4-OHBaA, 1-OHPy (NCI Chemical Carcinogen Repository, MO, USA), and $\mathrm{E}_{2}$ (water-soluble type, Sigma-Aldrich, Inc., MO, USA) were purchased and used in the present study. A $1 \%$ penicillin-streptomycin mixture (ICN Biomedicals, Inc., OH, USA) was added to Eagle's modified minimum essential medium (MEM; ICN Biomedicals, Inc.). HEPES (Research Organics, Inc., OH, USA) $(20 \mathrm{mM})$ was added to MEM and adjusted to $\mathrm{pH}$ 7.0. After filtration, MEM was used in this experiment. Scales were collected from goldfish and wrasse under anesthesia with ethyl 3-aminobenzoate, methanesulfonic acid salt (MS-222, Sigma-Aldrich, Inc.). The scales were cut into halves. One half of a piece was then placed into a well of a 24-well microplate in MEM (1 $\mathrm{ml})$ supplemented with OHPAHs or $\mathrm{E}_{2}\left(10^{-7}, 10^{-6}\right.$, and $\left.10^{-5} \mathrm{M}\right)$. The other half was also placed into a well of a 24-well microplate in an $\mathrm{OHPAH} / \mathrm{E}_{2}$-free medium as a control. Eight scales were used for each dose. The results are shown as the means \pm SEM of eight scales. These scales were incubated for 6 and $18 \mathrm{hrs}$ at $15^{\circ} \mathrm{C}$. After incubation, each incubated scale was washed with saline and transferred to its own well in a 96-well microplate. An aliquot of $100 \mu$ of $20 \mathrm{mM}$ tartrate in a $0.1 \mathrm{M}$ sodium acetate buffer ( $\mathrm{pH} 5.3$ ) was added to each well. This microplate was frozen at $-85^{\circ} \mathrm{C}$ immediately and kept at $-20{ }^{\circ} \mathrm{C}$ until analysis.

To analyze the TRAP activity, an aliquot of $100 \mu \mathrm{l}$ of $20 \mathrm{mM}$ para-nitrophenyl-phosphate in a 0.1 
M sodium acetate buffer was added to each well of a melted solution in the microplate. This plate was incubated at $20{ }^{\circ} \mathrm{C}$ for 30 min while being shaken. After incubation, the reaction was stopped by adding $50 \mu \mathrm{l}$ of a $3 \mathrm{~N} \mathrm{NaOH}-20 \mathrm{mM}$ EDTA solution. A colored solution of $150 \mu \mathrm{l}$ was transferred to a new plate, and the absorbance was measured at $405 \mathrm{~nm}$. The absorbance was converted into the amount of produced para-nitrophenol (pNP) using a standard curve for pNP. Detail methods were described in Persson et al. (1995, 1999) and Suzuki et al. (2007).

\section{Effects of OHPAHs and $E_{2}$ on osteoblastic activity in cultured scales of goldfish and wrasse}

Goldfish and wrasse were anesthetized with MS-222 (Sigma-Aldrich, Inc.), and scales were collected from them. The scales were cut into halves. One half of a piece was then placed into a well of a 24-well microplate in MEM (1 ml) supplemented with OHPAHs or $\mathrm{E}_{2}\left(10^{-7}, 10^{-6}\right.$, and $10^{-5}$ M). The other half was also placed into a well of a 24-well microplate as a control. Eight scales were used for each dose. The results are shown as the means \pm SEM of eight scales. These scales were incubated for 6 and $18 \mathrm{hrs}$ at $15^{\circ} \mathrm{C}$. After incubation, each incubated scale was washed with saline and transferred to its own well in a 96-well microplate. An aliquot of $100 \mu$ of an alkaline buffer (100 mM Tris-HCl, pH 9.5; $1 \mathrm{mM} \mathrm{MgCl}_{2} ; 0.1 \mathrm{mM} \mathrm{ZnCl}_{2}$ ) was added to each well. This microplate was frozen at $-85^{\circ} \mathrm{C}$ immediately and kept at $-20{ }^{\circ} \mathrm{C}$ until analysis.

The ALP activities were measured in the same manner as for the measurement of TRAP activity.

\section{Changes in cathepsin $\mathrm{K}$ (osteoclastic marker) and IGF-I (osteoblastic marker) mRNA expressions in 4-OHBaA-treated goldfish scales}

Scales were collected from goldfish under anesthesia with MS-222 and cut into halves. One half of a piece was then put into a microtube in $\operatorname{MEM}(1 \mathrm{ml})$ supplemented with 4-OHBaA $\left(10^{-5} \mathrm{M}\right)$ or $\mathrm{E}_{2}$ $\left(10^{-6} \mathrm{M}\right)$. The other half was also put into another microtube in a 4-OHBaA- or $\mathrm{E}_{2}$-free medium as a control. To examine changes in cathepsin $\mathrm{K}$ and IGF-I mRNA expressions in response to 
4-OHBaA, the scales were incubated for 6 and 18 hrs in MEM (containing an antibiotic and 20 $\mathrm{mM}$ HEPES) at $15^{\circ} \mathrm{C}$. The mRNA expression in the control and experimental scales in the same individual was compared. After incubation, the scales were frozen at $-85^{\circ} \mathrm{C}$ for mRNA analysis.

Total RNAs were prepared from goldfish scales using a total RNA isolation kit for fibrous tissue (Qiagen GmbH, Hilden, Germany). Complementary DNA synthesis was performed using a kit (Qiagen GmbH). PCR was carried out with Taq polymerase (Nippon Gene, Tokyo, Japan). Gene-specific primers for cathepsin K (5': GCTATGGAGCCACACCAAAAGG; 3’: CTGCGCTTCCAGCTCTCACAT) (Azuma et al. 2007) and for IGF-I (5': GGAGACGCTGTGCGGG; 3': CCTCAGCTCACAGCTCTG) (Kermouni et al. 1998) were used. The amplification of $\beta$-actin cDNA using a primer set (5': CGAGCGTGGCTACAGCTTCA; 3': GCCCGTCAGGGAGCTCATAG) (Azuma et al. 2007) was performed. The conditions for PCR amplification were denaturation for $0.5 \mathrm{~min}$ at $96{ }^{\circ} \mathrm{C}$, annealing for $1 \mathrm{~min}$ at $53-60{ }^{\circ} \mathrm{C}$, and extension for $2 \mathrm{~min}$ at $72{ }^{\circ} \mathrm{C}$ followed by a single cycle at $72{ }^{\circ} \mathrm{C}$ for $30 \mathrm{~min}$. The numbers of cycles for amplification in cathepsin K, IGF-I, and $\beta$-actin cDNAs were determined by ensuring that PCR amplification was at submaximum and the intensity of the band corresponded exactly to the amount of the starting material. The PCR products were analyzed on a $2.5 \%$ NuSive GTG agarose gel (FMC BioProducts, ME, USA) and stained with ethidium bromide. The band densities were estimated using a computer program (NIH Image J). The cathepsin K and IGF-I mRNA levels were normalized to the $\beta$-actin mRNA level.

\section{Statistical analysis}

The statistical significance was assessed by the student's t-test. The data for the cathepsin K and IGF-I mRNA levels were analyzed using the paired t-test. The selected significance level was $\mathrm{P}<0.05$. 


\section{RESULTS}

\section{Effects of OHPAHs and $E_{2}$ on osteoclastic activity in cultured scales of goldfish and wrasse}

In goldfish, the TRAP activity of the scales was significantly lowered by 4-OHBaA treatment at 6 hrs of incubation $\left(10^{-7}\right.$ and $\left.10^{-6} \mathrm{M}, \mathrm{P}<0.05,10^{-5} \mathrm{M}, \mathrm{P}<0.01\right)$ (Fig. 1) and $18 \mathrm{hrs}$ of incubation $\left(10^{-5}\right.$ $\mathrm{M}, \mathrm{P}<0.01$ )(Fig. 2), although the TRAP activity did not change from that of the control with 1-OHPy (data not shown). $\mathrm{E}_{2}$ significantly increased the TRAP activity at $6 \mathrm{hrs}\left(10^{-6}\right.$ and $10^{-5} \mathrm{M}$, $\mathrm{P}<0.05$ )(Fig. 1) and 18 hrs of incubation $\left(10^{-7}\right.$ and $\left.10^{-6} \mathrm{M}, \mathrm{P}<0.05 ; 10^{-5} \mathrm{M}, \mathrm{P}<0.01\right)$ (Fig. 2).

In the scales of wrasse after 4-OHBaA $\left(10^{-7}\right.$ to $\left.10^{-5} \mathrm{M}\right)$ treatment, the TRAP activity also decreased at 6 hrs $\left(10^{-6} \mathrm{M}, \mathrm{P}<0.05,10^{-5} \mathrm{M}, \mathrm{P}<0.01\right)$ (Fig. 3) and 18 hrs of incubation $\left(10^{-5} \mathrm{M}, \mathrm{P}<0.05\right)$ (Fig. 4). There was no change in the TRAP activity in 1-OHPy-treated scales (data not shown). In wrasse as well as goldfish, a significant difference (at $18 \mathrm{hrs}, 10^{-5} \mathrm{M}, \mathrm{P}<0.01$ ) was obtained between $\mathrm{E}_{2}$-treated scales and control scales (Fig. 4).

In the case of 3-OHBaA, the TRAP activities in both goldfish and wrasse scales were significantly decreased at 6 hrs of incubation $\left(10^{-5} \mathrm{M}, \mathrm{P}<0.05\right)$ (data not shown).

\section{Effects of OHPAHs and $E_{2}$ on osteoblastic activity in cultured scales of goldfish and wrasse}

In goldfish scales, at $6 \mathrm{hrs}$ of incubation, the ALP activity significantly decreased from the control values as a result of 4-OHBaA treatment $\left(10^{-5} \mathrm{M}, \mathrm{P}<0.01\right)$ (Fig. 5), while the ALP activity did not change with 1-OHPy treatment (data not shown). At $18 \mathrm{hrs}$ of incubation, there was no significant change in ALP activity (Fig. 6). $\mathrm{E}_{2}$ significantly increased the ALP activity at 6 hrs of incubation $\left(10^{-6} \mathrm{M}, \mathrm{P}<0.01 ; 10^{-5} \mathrm{M}, \mathrm{P}<0.05\right)$ (Fig. 5) and $18 \mathrm{hrs}$ of incubation $\left(10^{-7}, 10^{-6}\right.$, and $10^{-5} \mathrm{M}$, $\mathrm{P}<0.05)$ (Fig. 6).

Similar changes were induced by $4-\mathrm{OHBaA}$ in the scales of wrasse. The ALP activity significantly decreased in 4-OHBaA-treated wrasse scales at 6 hrs (4-OHBaA: $\left.10^{-5} \mathrm{M}, \mathrm{P}<0.01\right)($ Fig. 7) and 18 hrs of incubation (4-OHBaA: $10^{-5} \mathrm{M}, \mathrm{P}<0.01$ )(Fig. 8), although the ALP activity did not change 
from that of the control with 1-OHPy (data not shown). In wrasse, a significant difference (at 6 hrs: $10^{-5} \mathrm{M}, \mathrm{P}<0.01$; at 18 hrs: $10^{-6}$ and $10^{-5} \mathrm{M}, \mathrm{P}<0.01$ ) was obtained between $\mathrm{E}_{2}$-treated scales and control scales (Figs. 7 and 8).

In the case of 3-OHBaA, ALP activity in the goldfish scales was significantly decreased at 6 hrs of incubation $\left(10^{-5} \mathrm{M}, \mathrm{P}<0.05\right)$ (data not shown). In wrasse as well, ALP activity in the 3-OHBaA-treated scales significantly decreased at $6 \mathrm{hrs}\left(10^{-5} \mathrm{M}, \mathrm{P}<0.05\right)$ and $18 \mathrm{hrs}\left(10^{-5} \mathrm{M}\right.$, $\mathrm{P}<0.05$ ) of incubation (data not shown).

\section{Changes in cathepsin K and IGF-I mRNA expressions in 4-OHBaA-treated goldfish scales}

The results are indicated in Figs. 9 and 10. At 6 hrs of incubation, as indicated by analysis using the paired t-test, the expressions of cathepsin $\mathrm{K}$ and IGF-I mRNAs in 4-OHBaA $\left(10^{-5} \mathrm{M}\right)$-treated scales were significantly lower than those in the control scales (cathepsin K: $\mathrm{P}<0.01$; IGF-I: $\mathrm{P}<0.05$ ). Cathepsin $\mathrm{K}$ mRNA expression significantly $(\mathrm{P}<0.05)$ decreased by 4-OHBaA treatment at $18 \mathrm{hrs}$ of incubation, while IGF-I mRNA expression did not change significantly with the same incubation time. On the other hand, the cathepsin K and IGF-I mRNA expressions significantly increased as a result of the $\mathrm{E}_{2}\left(10^{-6} \mathrm{M}\right)$ treatment at both $6 \mathrm{hrs}$ (cathepsin $\mathrm{K}$ : $\mathrm{P}<0.05$; IGF-I: $\left.\mathrm{P}<0.05\right)$ and $18 \mathrm{hrs}$ (cathepsin K: P<0.01; IGF-I: P<0.01).

These changes were quite similar to the above changes in TRAP and ALP activity.

\section{Discussion}

Using our original assay system, OHPAHs (3-OHBaA and 4-OHBaA) suppressed the osteoclastic and osteoblastic activity in goldfish scales. The mRNA expressions of both cathepsin K (an osteoclastic marker) and IGF-I (an osteoblastic marker) decreased in 4-OHBaA-treated scales in the same way as the respective osteoclast and osteoblast marker enzymes did. This is the first report in which the direct influence of OHPAHs on osteoclasts and osteoblasts is demonstrated. In 
developing teleosts, spinal deformity was induced in Pacific herring and pink salmon by PAHs (Barron et al. 2004; Billiard et al. 2006). In fish, as well as in mammals, it is known that PAHs are converted into OHPAHs by the enzyme cytochrome P4501A1 (Charles et al. 2000; Billiard et al. 2006; Jaruchotikamol et al. 2007; Mortensen and Arukwe 2007). We believe that OHPAHs converted by this enzyme suppress both osteoclasts and osteoblasts and disrupt the bone metabolism. Storm water runoff and atmospheric deposition of PAHs are now the largest sources of aquatic PAH contamination (Lima et al. 2003; Li and Daler 2004). Furthermore, an oil spill from an oil tanker, such as the Exxon Valdez and Nakhodka, directly induces contamination by PAHs in a marine environment (Bue et al. 1998; Heintz et al. 2000; Hayakawa et al. 2006). In the Nakhodka C-heavy oil, $210 \mu \mathrm{g} / \mathrm{g}$ of benz[a]anthracene having four aromatic rings was detected (Hayakawa et al. 2006). This concentration is similar to that in the present experiment. Immediately after an oil spill, the high level of PAHs influenced marine animals, including fish. For a long time (more than 14 years), the toxicity of PAHs originating from an oil spill affected many marine animals (for a review, see Peterson et al. 2003). These facts, in conjunction with the findings of our study, indicate that careful attention should be given to aquatic PAH contamination.

$E_{2}$-specific binding (Persson et al. 2000) and ER $\alpha$ mRNA expression (Yoshikubo et al. 2005) were detected in the scales. However, a different action from $E_{2}$-treated scales was obtained in OHPAH-treated scales. In the case of bisphenol-A, which bound to mammalian ER $\alpha$ (Singleton et al. 2006), we previously reported that both osteoclastic and osteoblastic activities were significantly suppressed by bisphenol-A treatment (Suzuki and Hattori 2003). In a yeast two-hybrid assay with human ER $\alpha$, the amounts of estrogenic OHPAHs were much smaller than those of anti-estrogenic OHPAHs (Hayakawa et al. 2007). Most OHPAHs indicated an anti-estrogenic action (Hayakawa et al. 2007). We believe that in teleosts, as well as in humans, estrogenic substances are quite limited and that 3-OHBaA and 4-OHBaA induce actions that are different from those of estrogen and could be considered anti-estrogenic. To examine the effects of 
OHPAHs on bone tissues in detail, plans are underway to conduct micro-array analyses using the scales of zebrafish.

The present study indicated that the strength of the inhibition activity in goldfish was stronger than that in wrasse. In goldfish, even at $10^{-7} \mathrm{M}$ of 4-OHBaA, the osteoclastic activity was significantly inhibited. Exchange of calcium in the scales of freshwater teleosts may be faster than that in marine teleosts because they live in a low-calcium environment. In fact, the response of estrogen and calcitonin in the scales of freshwater teleosts was higher than that in those of marine teleosts (Persson et al. 1994, 1995; Suzuki et al. 2000; Guerreiro et al. 2002). Therefore, OHPAHs are more effective in freshwater teleosts.

In the present study, osteoclasts responded more sensitively to OHPAHs than osteoblasts. In goldfish, even $10^{-7} \mathrm{M}$ of 4-OHBaA inhibited the osteoclastic activity. In wrasse as well, $10^{-6} \mathrm{M}$ of 4-OHBaA caused a response in osteoclasts. In addition, at $18 \mathrm{hrs}$ of incubation, a significant difference in IGF-I mRNA expression was not obtained by 4-OHBaA treatment, while cathepsin K mRNA expression in the 4-OHBaA-treated scale was significantly lower than that in the control scale. This suggests that osteoclasts responded to OHPAHs sensitively according to the durable effect of OHPAH in osteoclasts.

Our in vitro assay system can simultaneously detect the activities of both scale osteoclasts and osteoblasts with TRAP and ALP as markers (Persson et al. 1995; Witten 1997; Grotmol et al. 2005; Suzuki et al. 2008), as shown by the fact that, in mammals, the effects of hormones and some bioactive substances on osteoclasts and osteoblasts have been investigated using TRAP and ALP as respective markers (Vaes 1988; Dimai et al. 1998; Chen et al. 2002; Liu et al. 2002). The respective enzyme activity from one scale can be detected by transferring each scale into a 96-well microplate and directly incubating it with the substrate in each well. Using this in vitro system, we demonstrated for the first time that calcitonin, a hypocalcemic hormone, directly suppressed osteoclastic activity in teleosts as well as in mammals (Suzuki et al. 2000) and that melatonin, a 
major hormone secreted from the pineal gland, suppressed the functions in both osteoclasts and osteoblasts (Suzuki and Hattori 2002). The effect of melatonin on osteoclasts and osteoblasts was confirmed in rats and mice (Suzuki et al. 2008). In addition, the effects of endocrine disrupters, such as bisphenol-A (Suzuki and Hattori 2003) and tributyltin (Suzuki et al. 2006), and heavy metals, i.e., cadmium and organic mercury (Suzuki et al. 2004), on osteoblasts and osteoclasts have been examined. We indicated that cadmium (even at $10^{-13} \mathrm{M}$ ) had an effect on the osteoclastic activity in the scale (Suzuki et al. 2004). Furthermore, we demonstrated that the osteogenesis of regenerating scale is very similar to that of mammalian membrane bone and a good model of osteogenesis (Yoshikubo et al. 2005). In the present study, we sensitively evaluated the effect of OHPAHs on osteoclasts and osteoblasts. Thus, our assay system is very useful to evaluate the effect of environmental pollutants on the bone metabolism. We are planning to adopt this system for other substances.

\section{Acknowledgments}

This study was supported in part by grants to N.S. (Grant-in-Aid for Scientific Research (C) No. 18500375 by JSPS; Ground-based Research Announcement for Space Utilization by the Japan Space Forum), to K.H. (Grant-in-Aid for Scientific Research of ExTEND2005 by the Ministry of Environment in Japan), A.H. (Grant-in-Aid for Scientific Research (C) No. 18570055 by JSPS), to S.W. (Grant-in-Aid for Scientific Research (C) No. 20592355 by JSPS), and to H.M. (Grant-in-Aid for Scientific Research (C) No.20592168 by JSPS)

\section{References}

Azuma K, Kobayashi M, Nakamura M, Suzuki N, Yashima S, Iwamuro S, Ikegame M, Yamamoto T, Hattori A. Two osteoclastic markers expressed in multinucleate osteoclasts of goldfish scales. Biochemical and Biophysical Research Communications 362, 594-600, 2007 
Barron MG, Carls MG, Heintz R, Rice SD. Evaluation of fish early life-stage toxicity models of chronic embryonic exposures to complex polycyclic aromatic hydrocarbon mixtures. Toxicological Sciences 78, 60-67, 2004

Bereiter-Hahn J, Zylberberg L. Regeneration of teleost fish scale. Comparative Biochemistry and Physiology Part A 105, 625-641, 1993

Berg A. Studies on the metabolism of calcium and strontium in freshwater fish I: relative contribution of direct and intestinal absorption. Memorie dell'Istituto Italiano di Idrobiologia 23, 161-196, 1968

Billiard SM, Timme-Laragy AR, Wassenberg DM, Cockman C, Di Giulio RT. The role of the aryl hydrocarbon receptor pathway in mediating synergistic developmental toxicity of polycyclic aromatic hydrocarbons to zebrafish. Toxicological Sciences 92, 526-536, 2006

Bue BG, Sharr S, Seeb JE. Evidence of damage to pink salmon populations inhabiting Prince William Sound, Alaska, two generations after the Exxon Valdez oil spill. Transactions of the American Fisheries Society 127, 35-43, 1998

Camusso M, Vigano L, Balestrini R. Bioconcentration of trace metals in rainbow trout: a field study. Ecotoxicology and Environmental Safety 31, 133-141, 1995

Charles GD, Bartels MJ, Zacharewski TR, Gollapudi BB, Freshour NL, Carney EW. Activity of benzo $[a]$ pyrene and its hydroxylated metabolites in an estrogen receptor- $\alpha$ reporter gene assay. 
Toxicological Sciences 55, 320-326, 2000

Chen F-P, Lee N, Wang K-C, Soong Y-K, Huang K-E. Effect of estrogen and $1 \alpha, 25(\mathrm{OH})_{2}$-vitamin $\mathrm{D}_{3}$ on the activity and growth of human primary osteoblast-like cells in vitro. Fertility and Sterility 77, 1038-1043, 2002

Dimai HP, Linkhart TA, Linkhart SG, Donahue LR, Beamer WG, Rosen CJ, Farley JR, Baylink DJ. Alkaline phosphatase levels and osteoprogenitor cell numbers suggest bone formation may contribute to peak bone density differences between two inbred strains of mice. Bone 22, 211-216, 1998

Ebright RH, Wong JR, Chen LB. Binding of 2-hydroxybenzo(a)pyrene to estrogen receptors in rat cytosol. Cancer Research 46, 2349-2351, 1986

Flores MV, Tsanga VWK, Hu W, Kalev-Zylinska M, Postlethwait J, Crosier P, Crosier K, Fisher S. Duplicate zebrafish runx2 orthologues are expressed in developing skeletal elements. Gene Expression Patterns 4, 573-581, 2004

Glenney GW, Wiens GD. Early diversification of the TNF superfamily in teleosts: genomic characterization and expression analysis. The Journal of Immunology 178, 7955-7973, 2007

Grotmol S, Nordvik K, Kryvi H, Totland GK. A segmental pattern of alkaline phosphatase activity within the notochord coincides with the initial formation of the vertebral bodies. Journal of Anatomy 206, 427-436, 2005 
Guerreiro PM, Fuentes J, Canario AVM, Power DM. Calcium balance in sea bream (Sparus aurata): the effect of oestradiol-17 $\beta$. Journal of Endocrinology 173, 377-385, 2002

Hayakawa K, Nomura M, Nakagawa T, Oguri S, Kawanishi T, Toriba A, Kizu R, Sakaguchi T, Tamiya E. Damage to and recovery of coastlines polluted with C-heavy oil spilled from the Nakhodka. Water Research 40, 981-989, 2006

Hayakawa K, Onoda Y, Tachikawa C, Hosoi S, Yoshita M, Chung SW, Kizu R, Toriba A, Kameda T, Tang N. Estrogenic/antiestrogenic activities of polycyclic aromatic hydrocarbons and their monohydroxylated derivatives by yeast two-hybrid assay. Journal of Health Science 53, 562-570, 2007

Heintz RA, Rice SD, Wertheimer AC, Bradshaw RF, Thrower FP, Joyce JE, Short JW. Delayed effects on growth and marine survival of pink salmon Oncorhynchus gorbuscha after exposure to crude oil during embryonic development. Marine Ecology Progress Series 208, 205-216, 2000

Jaruchotikamol A, Jarukamjorn K, Sirisangtrakul W, Sakuma T, Kawasaki Y, Nemoto N. Strong synergistic induction of CYP1A1 expression by andrographolide plus typical CYP1A inducers in mouse hepatocytes. Toxicology and Applied Pharmacology 224, 156-162, 2007

Kermouni A, Mahmoud SS, Wang S, Moloney M, Habibi HR. Cloning of a full-length insulin-like growth factor-I complementary DNA in the goldfish liver and ovary and development of a quantitative PCR method for its measurement. General and Comparative Endocrinology 111, 51-60, 1998 
Lake JL, Ryba SA, Serbst JR, Libby AD. Mercury in fish scales as an assessment method for predicting muscle tissue mercury concentrations in largemouth bass. Archives of Environmental Contamination and Toxicology 50, 539-544, 2006

Lee LL, Lee JSC, Waldman SD, Casper RF, Grynpas MD. Polycyclic aromatic hydrocarbons present in cigarette smoke cause bone loss in an ovariectomized rat model. Bone 30, 917-923, 2002

Lehane DB, McKie N, Russell RGG, Henderson IW. Cloning of a fragment of the osteonectin gene from goldfish, Carassius auratus: its expression and potential regulation by estrogen. General and Comparative Endocrinology 114, 80-87, 1999

Li D, Daler D. Ocean pollution from land-based sources: east China Sea, China. Ambio 33, 107-113, 2004

Lima ALC, Eglinton TI, Reddy CM. High-resolution record of pyrogenic polycyclic aromatic hydrocarbon deposition during the 20th century. Environmental Science and Technology 37, 53-61, 2003

Liu B-Y, Wu P-W, Bringhurst FR, Wang J-T. Estrogen inhibition of PTH-stimulated osteoclast formation and attachment in vitro: involvement of both PKA and PKC. Endocrinology 143, $627-635,2002$

Mortensen AS, Arukwe A. Targeted salmon gene array (SalArray): a toxicogenomic tool for gene expression profiling of interactions between estrogen and aryl hydrocarbon receptor signaling pathways. Chemical Research in Toxicology 20, 474-488, 2007 
Mugiya Y, Watabe N. Studies on fish scale formation and resorption II: effect of estradiol on calcium homeostasis and skeletal tissue resorption in the goldfish, Carassius auratus, and the killifish, Fundulus heteroclitus. Comparative Biochemistry and Physiology Part A 57, 197-202, 1977

Nishimoto SK, Araki N, Robinson FD, Waite JH. Discovery of bone $\gamma$-carboxyglutamic acid protein in mineralized scales. The Journal of Biological and Chemistry 267, 11600-11605, 1992

Persson P, Sundell K, Björnsson BTh. Estradiol-17ß-induced calcium uptake and resorption in juvenile rainbow trout, Oncorhynchus mykiss. Fish Physiology and Biochemistry 13, 379-386, 1994

Persson P, Takagi Y, Björnsson BTh. Tartrate resistant acid phosphatase as a marker for scale resorption in rainbow trout, Oncorhynchus mykiss: effects of estradiol-17 $\beta$ treatment and refeeding. Fish Physiology and Biochemistry 14, 329-339, 1995

Persson P, Björnsson BTh, Takagi Y. Characterization of morphology and physiological actions of scale osteoclasts in the rainbow trout. Journal of Fish Biology 54, 669-684, 1999

Persson P, Shrimpton JM, McCormick SD, Björnsson BTh. The presence of high-affinity, low-capacity estradiol-17 $\beta$ binding in rainbow trout scale indicates a possible endocrine route for the regulation of scale resorption. General and Comparative Endocrinology 120, 35-43, 2000

Peterson CH, Rice SD, Short JW, Esler D, Bodkin JL, Ballachey BE, Irons DB. Long-term 
ecosystem response to the Exxon Valdez oil spill. Science 302, 2082-2086, 2003

Singleton DW, Feng Y, Yang J, Puga A, Lee AV, Khan SA. Gene expression profiling reveals novel regulation by bisphenol-A in estrogen receptor- $\alpha$-positive human cells. Environmental research 100, 86-92, 2006

Suzuki N, Suzuki T, Kurokawa T. Suppression of osteoclastic activities by calcitonin in the scales of goldfish (freshwater teleost) and nibbler fish (seawater teleost). Peptides 21, 115-124, 2000

Suzuki N, Hattori A. Melatonin suppresses osteoclastic and osteoblastic activities in the scales of goldfish. Journal of Pineal Research 33, 253-258, 2002

Suzuki N, Hattori A. Bisphenol A suppresses osteoclastic and osteoblastic activities in the cultured scales of goldfish. Life Sciences 73, 2237-2247, 2003

Suzuki N, Yamamoto M, Watanabe K, Kambegawa A, Hattori A. Both mercury and cadmium directly influence calcium homeostasis resulting from the suppression of scale bone cells: the scale is a good model for the evaluation of heavy metals in bone metabolism. Journal of Bone and Mineral Metabolism 22, 439-446, 2004

Suzuki N, Tabata MJ, Kambegawa A, Srivastav AK, Shimada A, Takeda H, Kobayashi M, Wada S, Katsumata T, Hattori A. Tributyltin inhibits osteoblastic activity and disrupts calcium metabolism through an increase in plasma calcium and calcitonin levels in teleosts. Life Science 78, 2533-2541, 2006 
Suzuki N, Kitamura K, Nemoto T, Shimizu N, Wada S, Kondo T, Tabata MJ, Sodeyama F, Ijiri K, Hattori A. Effect of vibration on osteoblastic and osteoclastic activities: analysis of bone metabolism using goldfish scale as a model for bone. Advance in Space Research 40, 1711-1721, 2007

Suzuki N, Somei M, Seki A, Reiter RJ, Hattori A. Novel bromomelatonin derivatives as potentially effective drugs to treat bone diseases. Journal of Pineal Research 45, 229-234, 2008

Vaes G. Cellular biology and biochemical mechanism of bone resorption. Clinical Orthopaedics and Related Research 231, 239-271, 1988

Witten PE. Enzyme histochemical characteristics of osteoblasts and mononucleated osteoclasts in a teleost fish with acellular bone (Oreochromis niloticus, Cichlidae). Cell and Tissue Reserach 287, 591-599, 2007

Yamada J. Studies on the structure and growth of the scales in the goldfish. Memoirs of the Faculty of Fisheries, Hokkaido University 9, 181-226, 1961

Yamada J. A fine structural aspect of the development of scales in the chum salmon fry. Bulletin of the Japanese Society of Scientific Fisheries 37, 18-29, 1971

Yoshikubo H, Suzuki N, Takemura K, Hoso M, Yashima S, Iwamuro S, Takagi Y, Tabata MJ, Hattori A. Osteoblastic activity and estrogenic response in the regenerating scale of goldfish, a good model of osteogenesis. Life Sciences 76, 2699-2709, 2005 
Zylberberg L, Bonaventure J, Cohen-Solal L, Hartmann DJ, Bereiter-Hahn J. Organization and characterization of fibrillar collagens in fish scales in situ and in vitro. Journal of Cell Science 103, 273-285, 1992 


\section{Figure legends}

Fig. 1. Effects of 4-OHBaA and $\mathrm{E}_{2}$ on tartrate-resistant acid phosphatase (TRAP) activity in cultured goldfish scales after 6 hrs of incubation. The TRAP activity of scales was measured as osteoclastic activity. ${ }^{*}$ and $* *$ indicate statistically significant differences at $\mathrm{P}<0.05$ and $\mathrm{P}<0.01$, respectively, from the values in the control scales.

Fig. 2. Effects of 4-OHBaA and $\mathrm{E}_{2}$ on TRAP activity in cultured goldfish scales after 18 hrs of incubation. The TRAP activity of scales was measured as osteoclastic activity. * and ** indicate statistically significant differences at $\mathrm{P}<0.05$ and $\mathrm{P}<0.01$, respectively, from the values in the control scales.

Fig. 3. Effects of 4-OHBaA and $\mathrm{E}_{2}$ on TRAP activity in cultured wrasse scales after 6 hrs of incubation. The TRAP activity of scales was measured as osteoclastic activity. * and ** indicate statistically significant differences at $\mathrm{P}<0.05$ and $\mathrm{P}<0.01$, respectively, from the values in the control scales.

Fig. 4. Effects of 4-OHBaA and $\mathrm{E}_{2}$ on TRAP activity in cultured wrasse scales after 18 hrs of incubation. The TRAP activity of scales was measured as osteoclastic activity. * and ** indicate statistically significant differences at $\mathrm{P}<0.05$ and $\mathrm{P}<0.01$, respectively, from the values in the control scales.

Fig. 5. Effects of 4-OHBaA and $E_{2}$ on alkaline phosphatase (ALP) activity in cultured goldfish scales after 6 hrs of incubation. The ALP activity of scales was measured as osteoblastic activity. * and ** indicate statistically significant differences at $\mathrm{P}<0.05$ and $\mathrm{P}<0.01$, respectively, from the values in the control scales. 
Fig. 6. Effects of 4-OHBaA and $\mathrm{E}_{2}$ on ALP activity in cultured goldfish scales after $18 \mathrm{hrs}$ of incubation. The ALP activity of scales was measured as osteoblastic activity. * indicates statistically significant difference at $\mathrm{P}<0.05$ from the values in the control scales.

Fig. 7. Effects of 4-OHBaA and $\mathrm{E}_{2}$ on ALP activity in cultured wrasse scales after 6 hrs of incubation. The ALP activity of scales was measured as osteoblastic activity. ** indicates statistically significant difference at $\mathrm{P}<0.01$ from the values in the control scales.

Fig. 8. Effects of 4-OHBaA and $\mathrm{E}_{2}$ on ALP activity in cultured wrasse scales after $18 \mathrm{hrs}$ of incubation. The ALP activity of scales was measured as osteoblastic activity. ** indicates statistically significant difference at $\mathrm{P}<0.01$ from the values in the control scales.

Fig. 9. Expression of cathepsin $\mathrm{K}$ mRNAs in 4-OHPAH $\left(10^{-5} \mathrm{M}\right)$ - and $\mathrm{E}_{2}\left(10^{-6} \mathrm{M}\right)$-treated scales of goldfish after 6 and $18 \mathrm{hrs}$ of incubation. * and ** indicate statistically significant differences at $\mathrm{P}<0.05$ and $\mathrm{P}<0.01$, respectively, from the values in the control scales. Statistical analysis was performed by the paired t-test.

Fig. 10. Expression of IGF-I mRNAs in 4-OHPAH $\left(10^{-5} \mathrm{M}\right)$ - and $\mathrm{E}_{2}\left(10^{-6} \mathrm{M}\right)$-treated scales of goldfish after 6 and $18 \mathrm{hrs}$ of incubation. * and ** indicate statistically significant differences at $\mathrm{P}<0.05$ and $\mathrm{P}<0.01$, respectively, from the values in the control scales. Statistical analysis was performed by the paired t-test. 
TRAP activity in goldfish

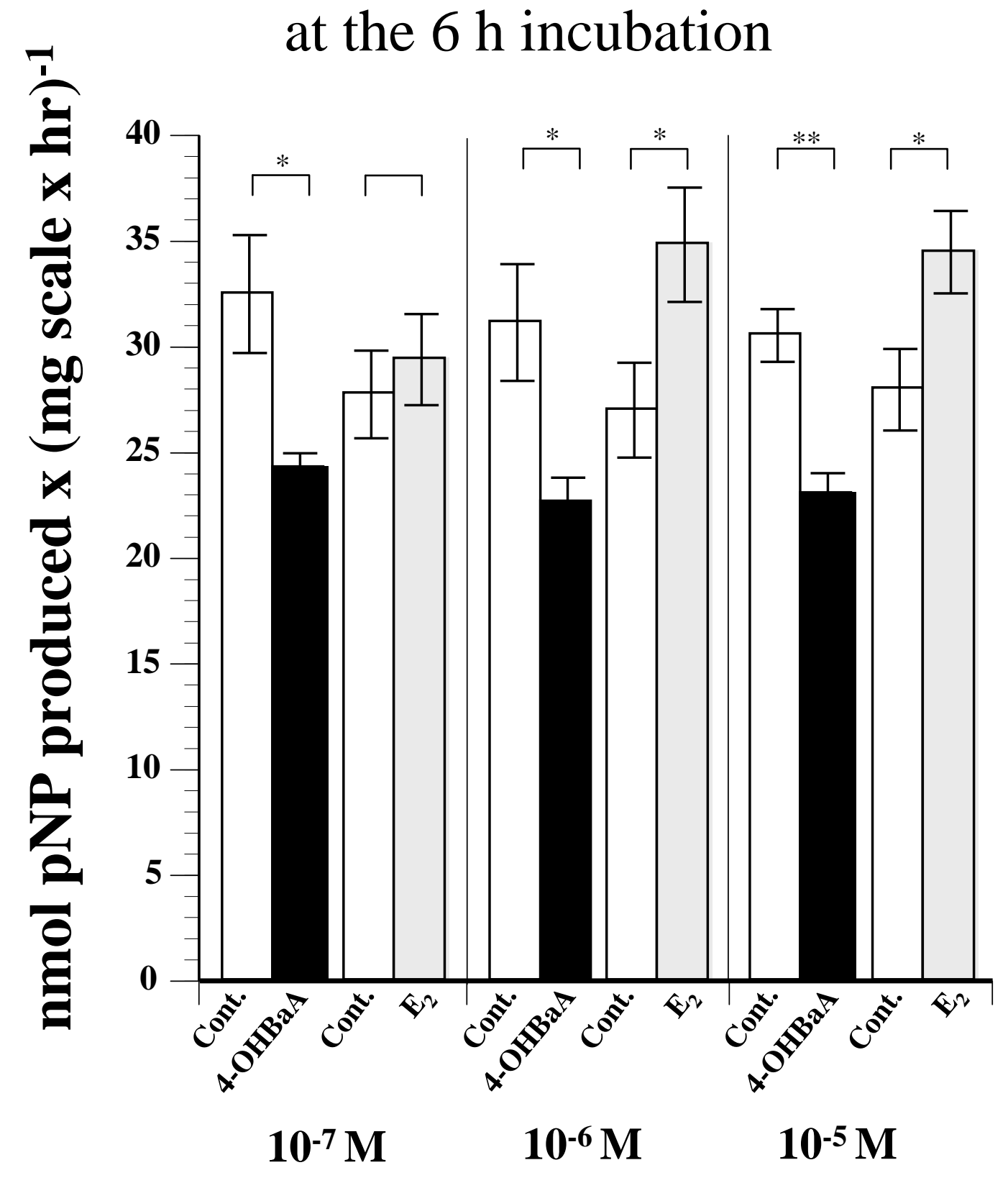

Figure 1 Suzuki et al. 
TRAP activity in goldfish

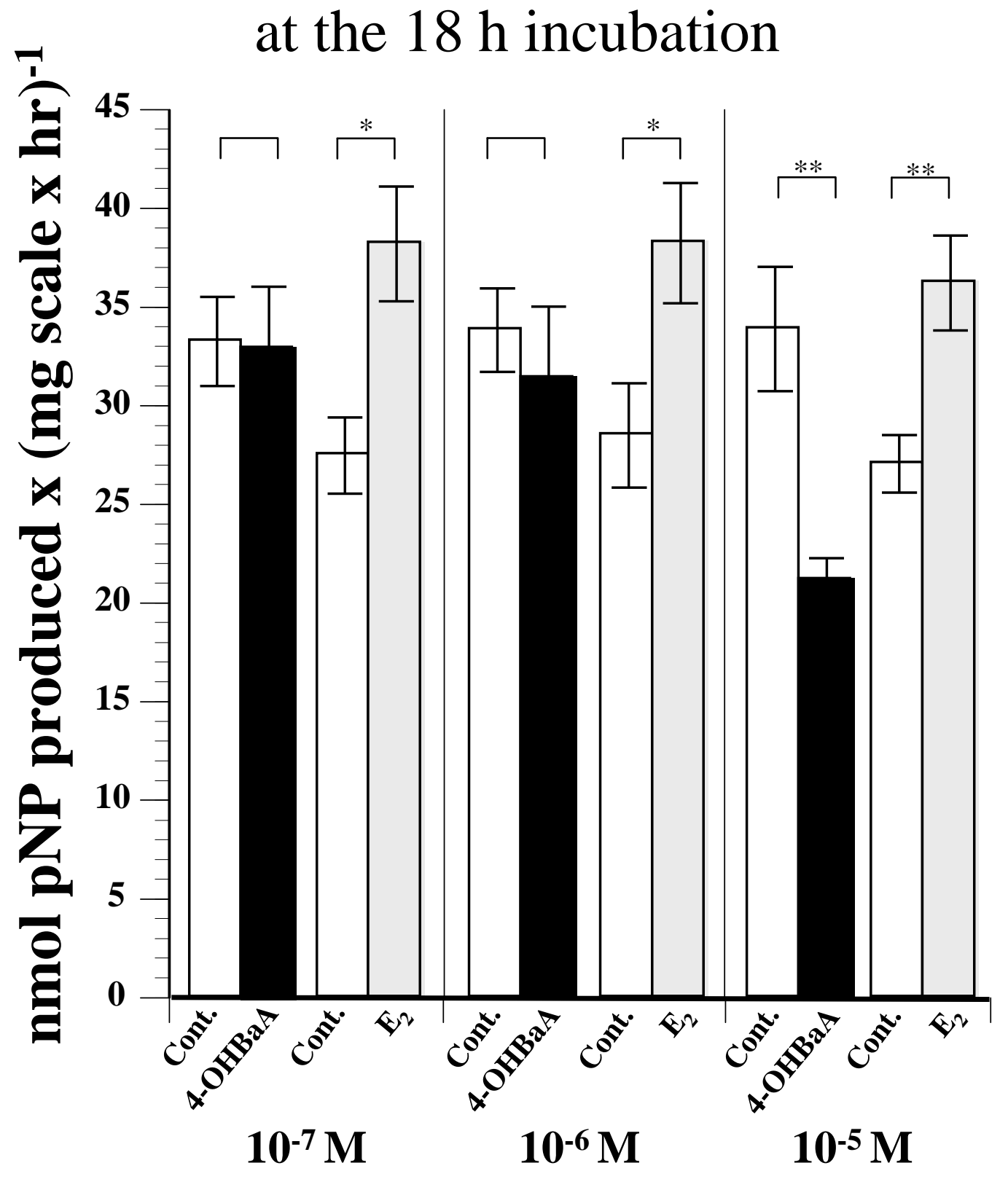

Figure 2 Suzuki et al. 
TRAP activity in wrasse

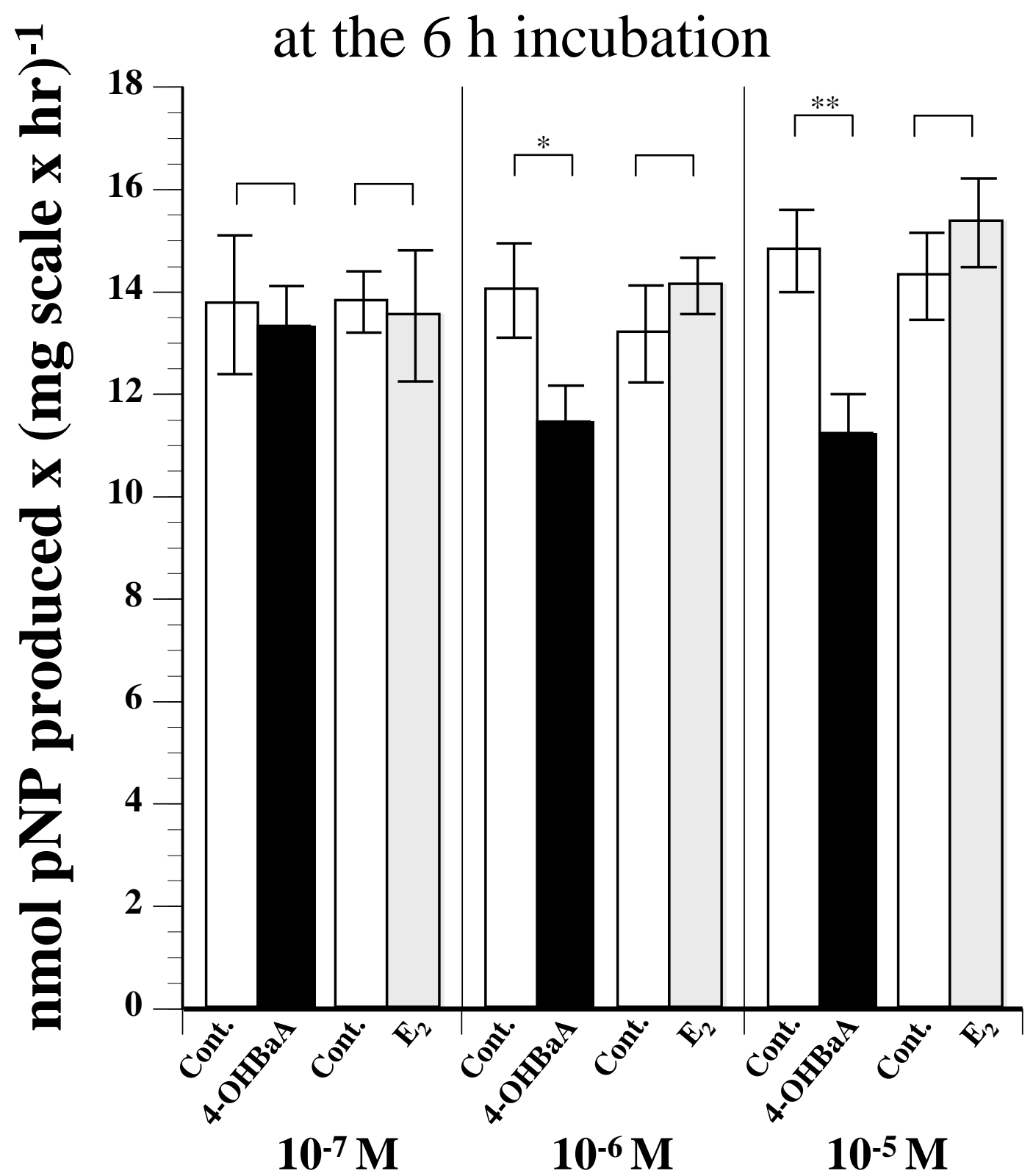

Figure 3 Suzuki et al. 
TRAP activity in wrasse

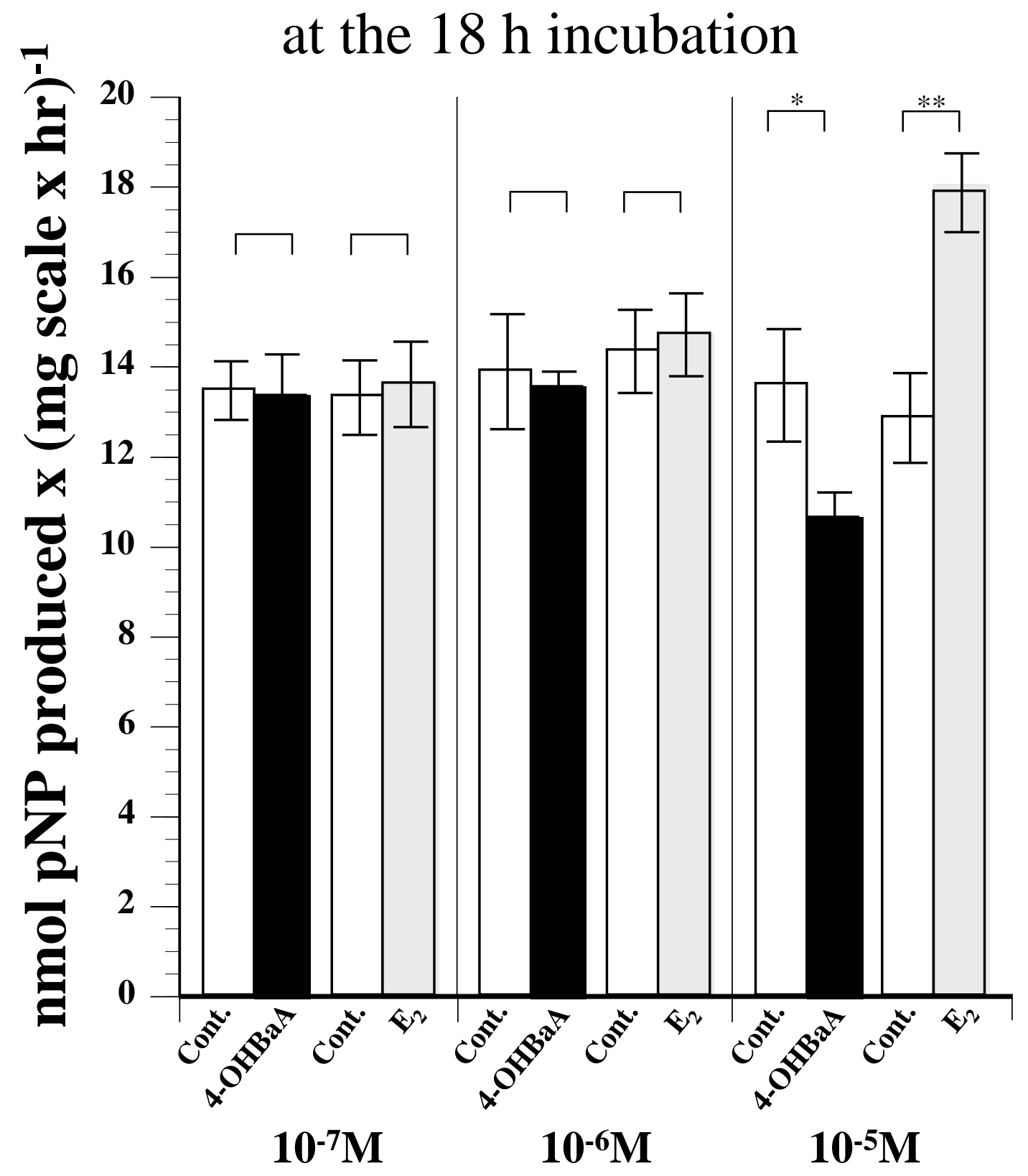

Figure 4 Suzuki et al. 
ALP activity in goldfish

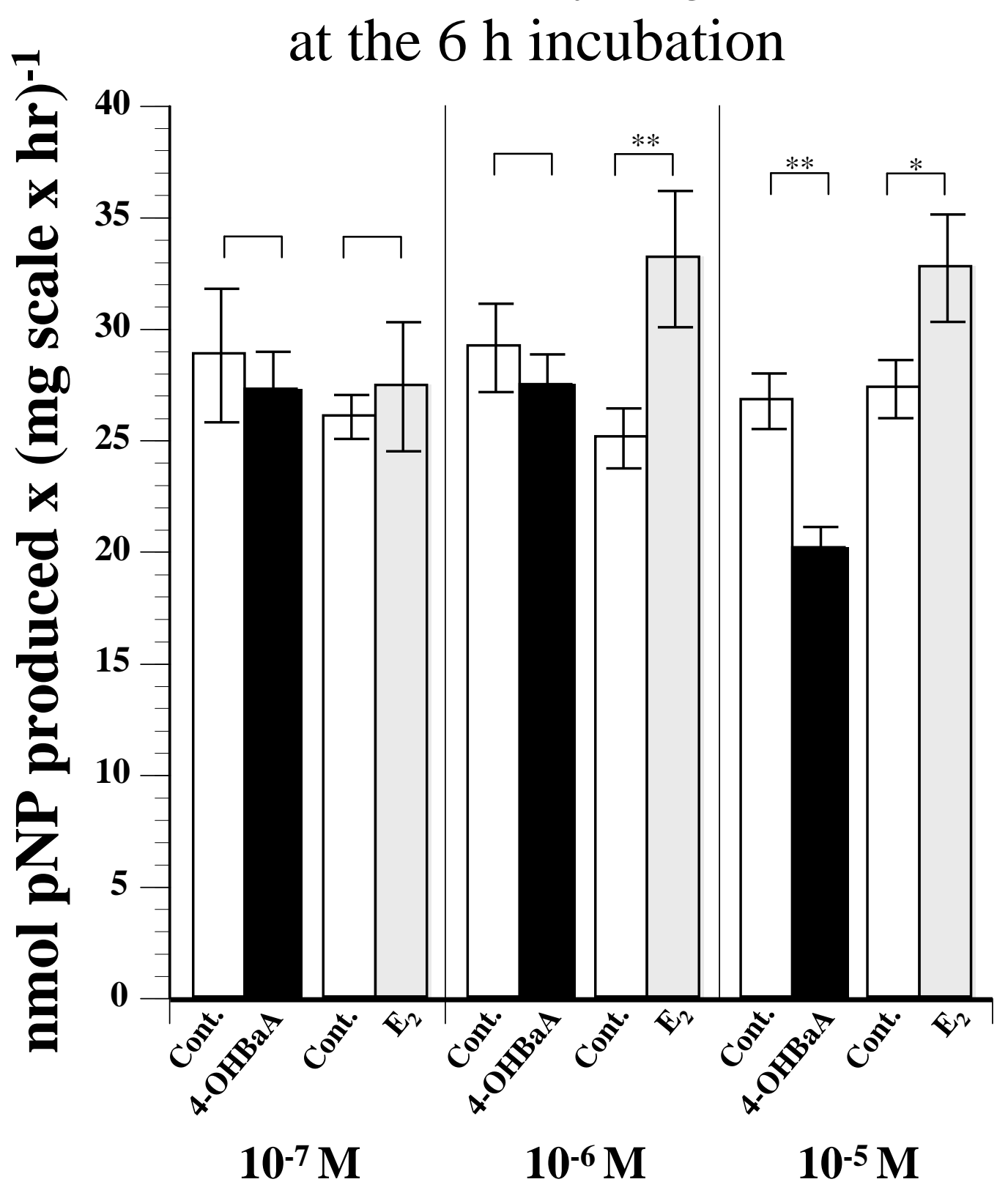

Figure 5 Suzuki et al. 
ALP activity in goldfish

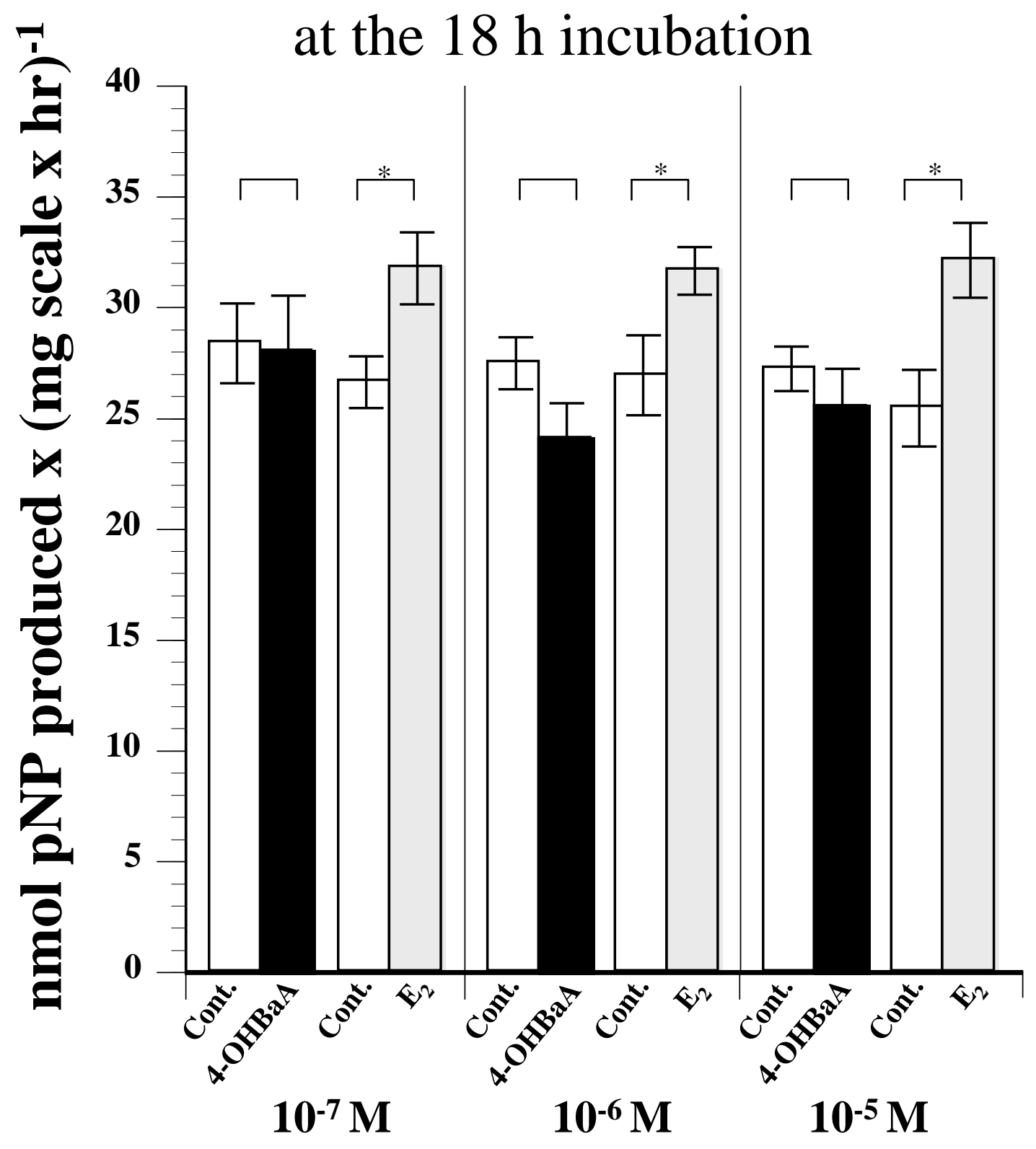

Figure 6 Suzuki et al. 
ALP activity in wrasse

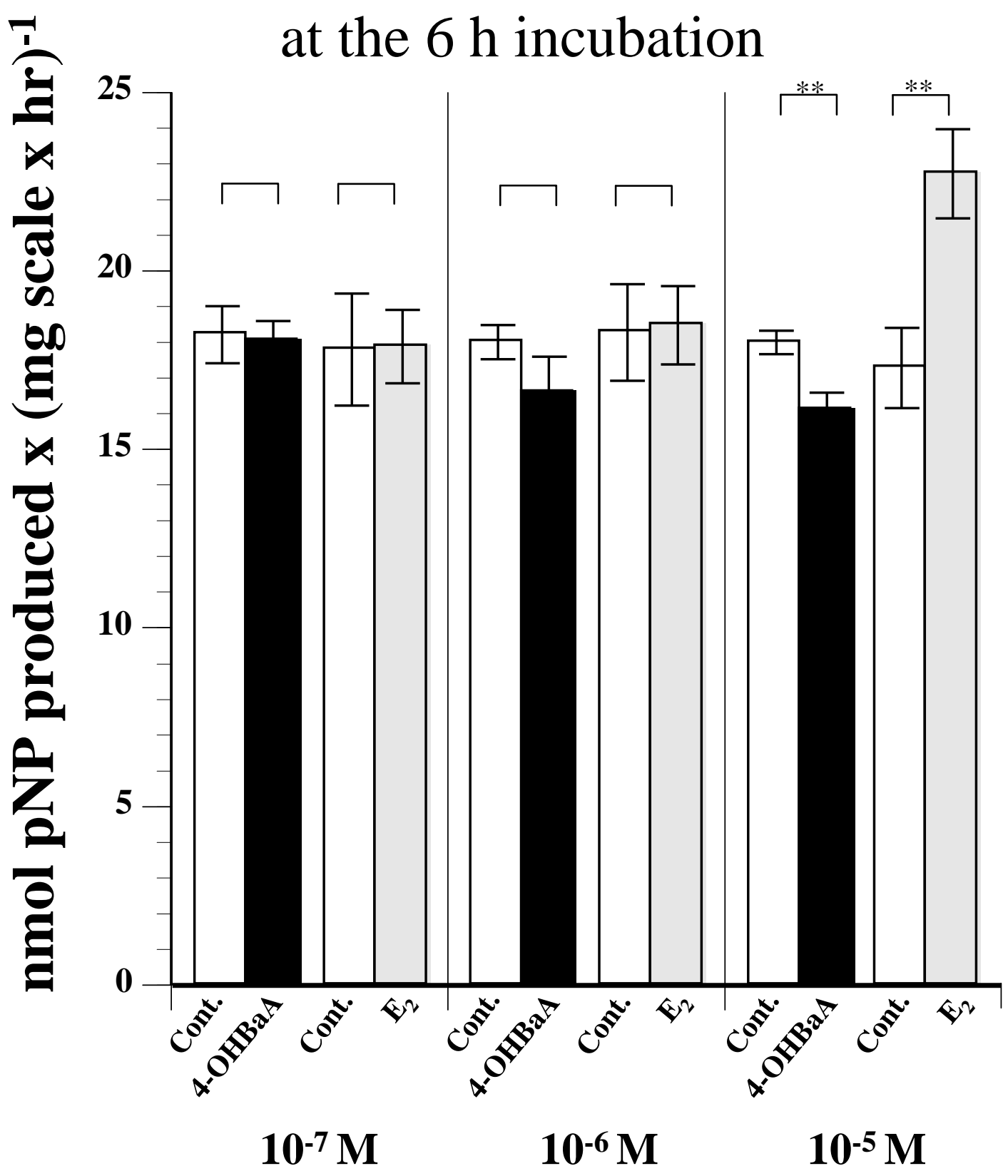

Figure 7 Suzuki et al. 
ALP activity in wrasse

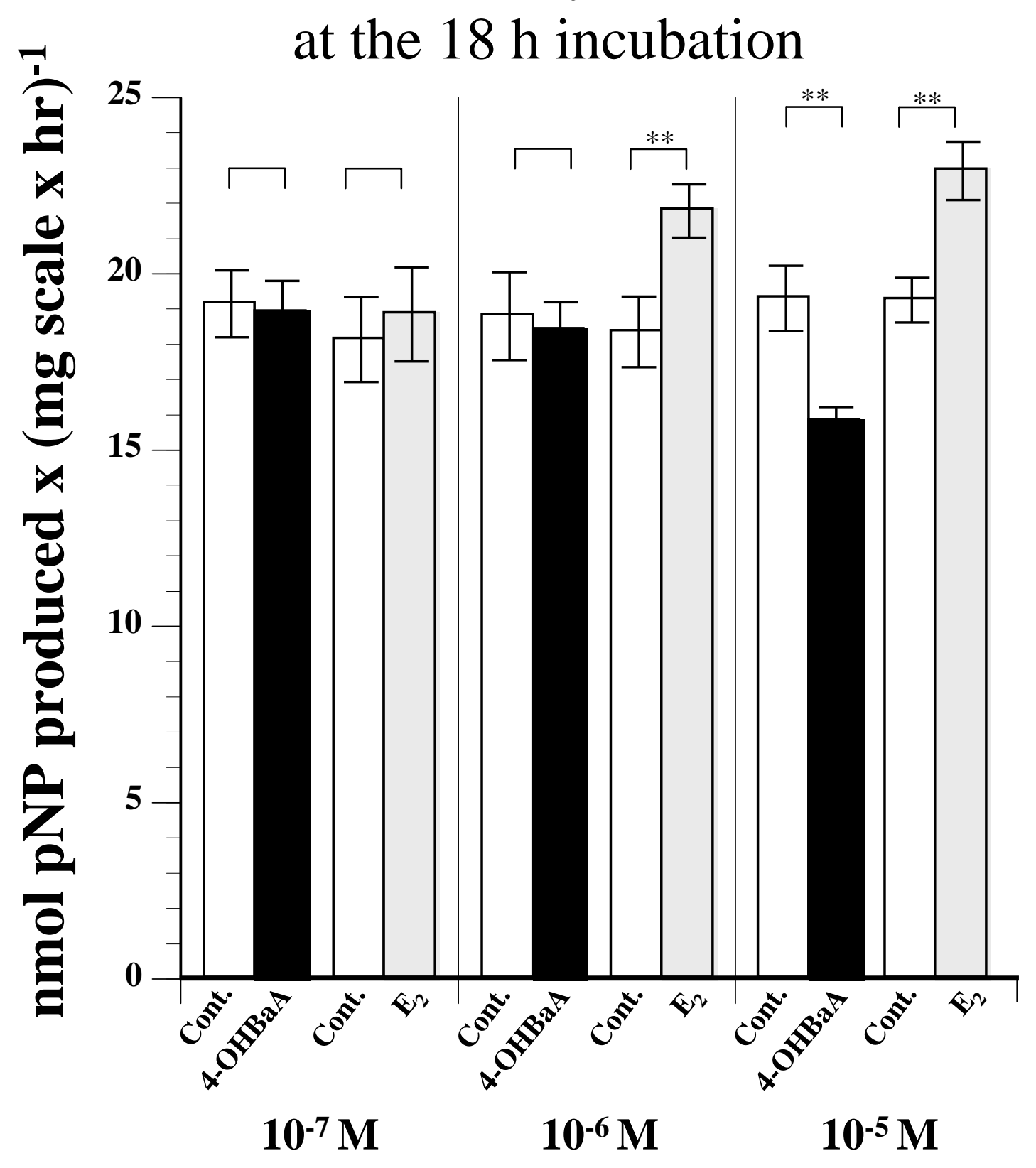

Figure 8 Suzuki et al. 


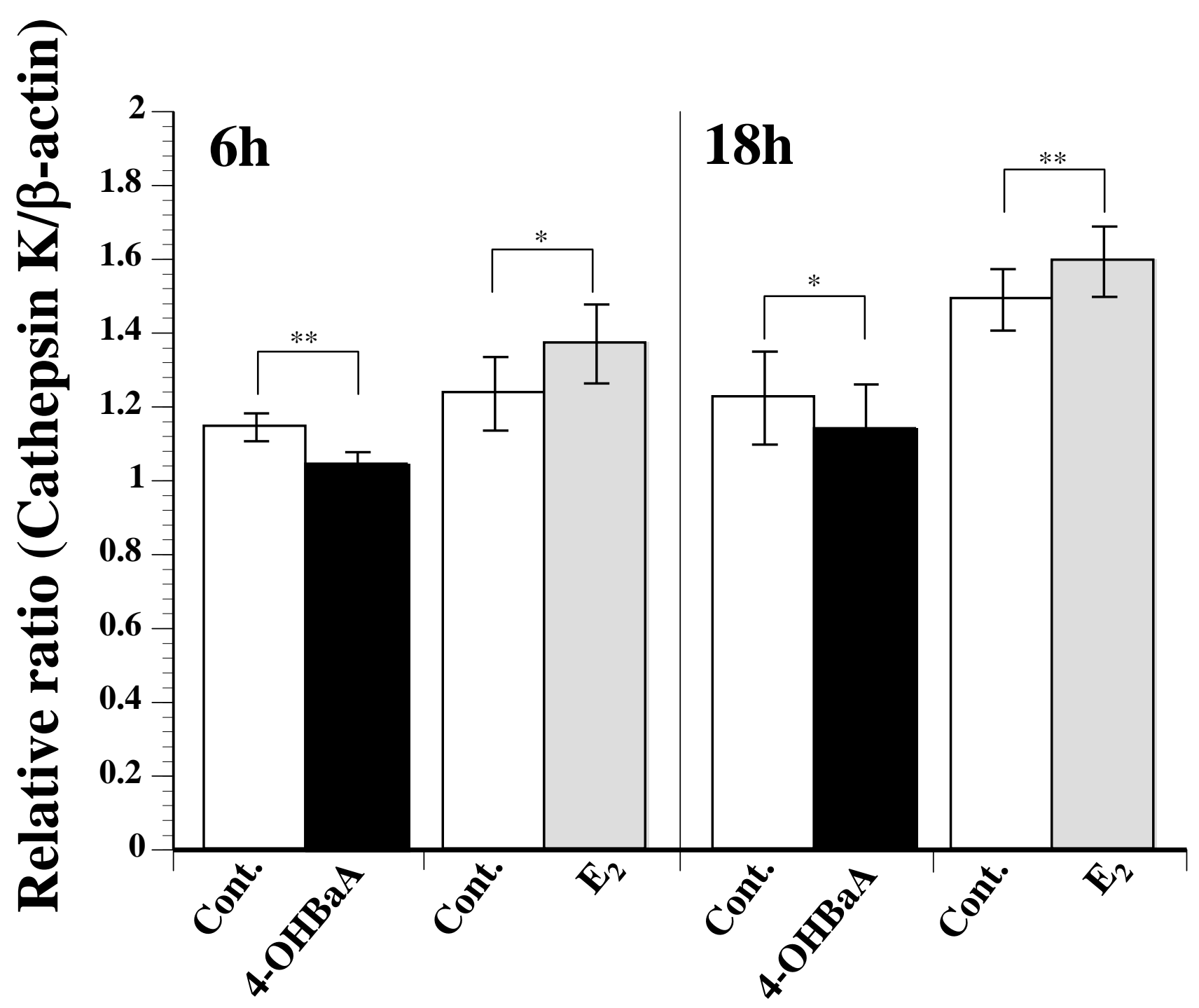

Figure 9 Suzuki et al. 


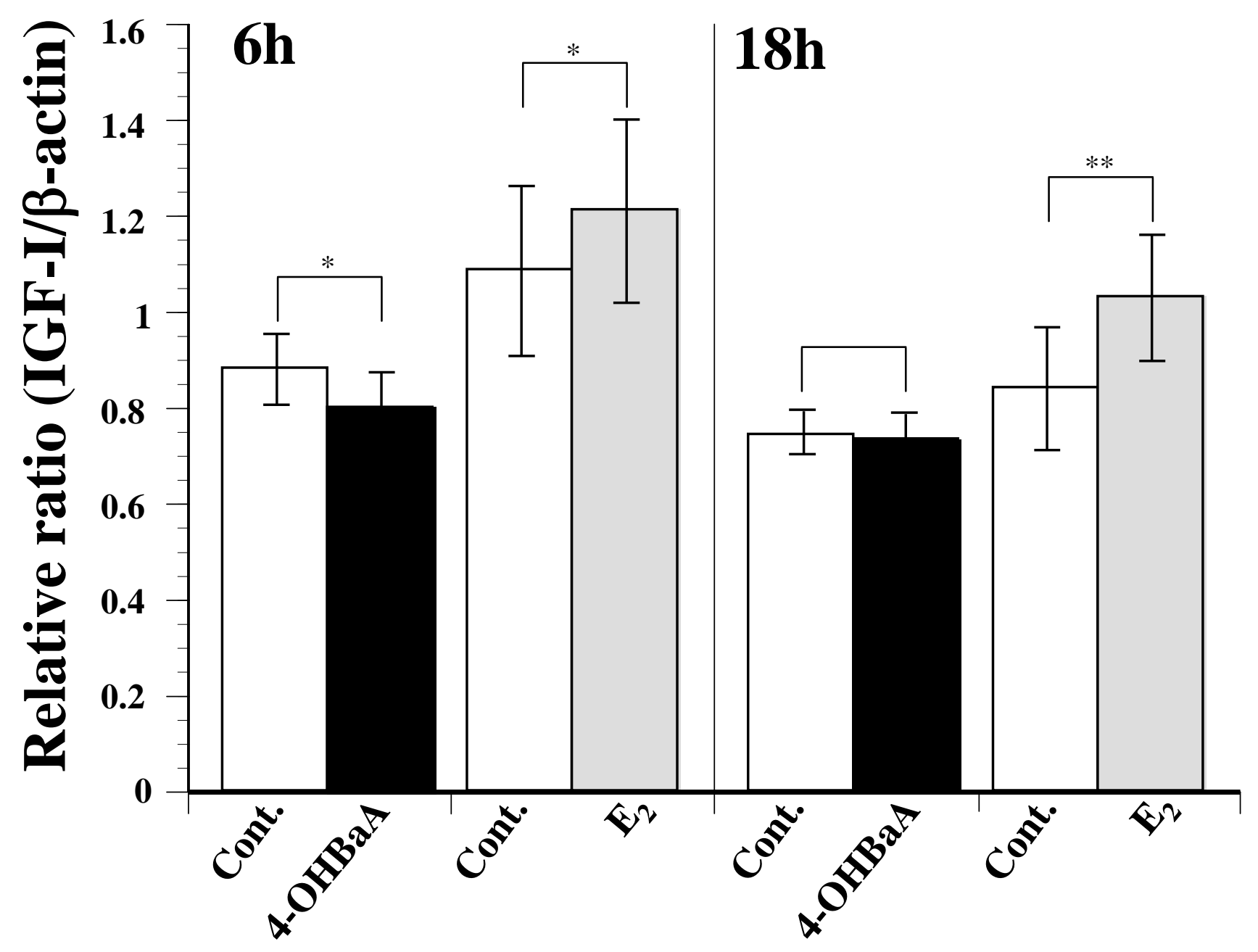

Figure 10 Suzuki et al. 